\title{
ROLE OF CERTAIN BEAUVERIA BASSIANA (BALS.) ISOLATE AS BIOLOGICAL CONTROL AGENT AGAINST COWPEA APHID (Aphis craccivora koch) AND ITS EFFECT ON THE PREDATOR Chrysopela carnea (STEPHENS). Imam, M. I' and Iman I. Imam ${ }^{2}$ 1-Entomology Department, Faculty of Science, Ain Shams University. 2-Economic Entomology Unit, Plant Protection Department, Desert Research Center.,
}

\begin{abstract}
The lethal effect of Beauveria bassiana isolate on Aphis craccivora revealed that the least percentage of adult mortality was $11 \%$, which was recorded with the lowest tested concentration $\left(1 \times 10^{3}\right.$ spores $\left./ \mathrm{ml}\right)$, while The highest percentage of adult mortality was $(54 \%)$ was achieved at $\left(1 \times 10^{7}\right.$ spores $\left./ \mathrm{ml}\right)$. compared with $4 \%$ in natural mortality. In a similar trial to evaluate the effect of $B$. bassiana against the aphid lion Chrysopela carnea (Stephens), exposure of the $2^{\text {nd }}$ larval instar of aphid lion to $B$. bassiana isolate either through direct or indirect exposure resulted in adverse effects on the total percent of larval mortality, which was concentration dependent. Whereas the total larval death recorded $3 \%$ in control trials, data in case of direct exposure revealed 9 to $41 \%$ of larval death at $1 \times 10^{3}$ and $1 \times 10^{7} \mathrm{spores} / \mathrm{ml}$, respectively, Comparable trend was recorded with larvae indirectly exposed. A slight increase in larval mortality was recorded by 5 to $15 \%$, respectively. In case of direct exposure technique the hatchability percentage decreased by increasing fungal concentration. The fluctuation in the indirect exposure technique did not statistically differ from that recorded in case of control trials.
\end{abstract}

\section{INTRODUCTION}

Natural enemies play a very important part in controlling pest populations. Green lacewing Chrysoperla carnea (Stephens), known as an insect in the Chrysopidae family. The adults feed on nectar, pollen and aphid honeydew and are not predatory, but the larvae are efficient biocontrolling predators against many key pests including aphids, whiteflies, young larvae and eggs of Lepidoptera, mealybugs, spider mites and soft bodied arthropods (El- Arnaouty \& Ferran 1993 and Hassan 2003). It can be mass reared in the laboratory and released against pests in field and green houses (Mirnoayedi, 2001).

Aphis craccivora cowpea aphid (Order / Homoptera: Family Aphididae) or plant lice, is one of the hundreds of different species of aphids. They are small soft-bodied insects some of which attack only one host plant while others attack numerous hosts.

Aphids feed by sucking up plant juices and at the same time, inject saliva into the host. Light infestations are usually not harmful to plants, but higher aphid infestations may result in leaf curl, wilting, stunting of shoot growth, and delay in production of flowers and fruit, as well as a general decline in plant vigor. Some aphids are also important vectors of plant diseases, transmitting pathogens in the feeding process. 
Fungal microbial control agent offer a method of insect pest control that can be integrated with other biocontrol agents, Beauveria bassiana (Bais.) was ubiquitous as an entomopathogen of a wide range of insect's from most insect orders (Goettel and Jaronski, 1997). However, the success of fungal entomopathogens as biological control agents depends not only on high efficacy against insect pests, but also on low virulence against non target insects.

Therefore the current investigation aims to study the role of certain $B$. bassiana isolate a biological control agent against $A$. craccivora and its effect on the chrysopid predator C. carnea.

\section{MATERIALS AND METHODS}

\section{1- Origin and maintenance of insect culture:}

A. craccivora kock (Homoptera: Aphididae) feed on bean plants (Vicia faba) by sucking plant juices. Numbers of pots were planted with seeds of bean. When the plant grew above the soil, artificial infestation was achieved by transferring heavily infested leaves to the new plants. Aphids were transferred weekly from old to young plants. The colony was maintained under laboratory conditions.

Rearing was carried out in a box, two sides of which were made up of wire mesh, the upper part was made up of glass, and the rest was wood.

The predator, C. carnea was initially collected from the cotton field and reared on Angoumois grain moth, Sitotroga cerealella (Olivier) at the same mentioned laboratory conditions. The adults of $C$. carnea were sexed and 10 pairs of adults were placed in plastic boxes $(22 \times 13 \times 10 \mathrm{~cm})$ covered with black muslin for deposited eggs and changed daily. Drops of Semi artificial diet solution consists of $2 \mathrm{~g}$ yeast extract, $1 \mathrm{~g}$ fructose and $1 \mathrm{~cm}$ distilled water were provided on tape stacked on the muslin cover. The deposited eggs were collected daily and kept in glass jars until hatching. The hatched larvae were reared on S. cerealella eggs. (Hassan and Ezz 2009).

The original colony of the predator and its prey were supplied from the Plant Protection Research Institute, Agriculture Research Centre. Mass rearing was carried out in the laboratory of the Economic Entomology Unit, Plant Protection Department, Desert Research Center.

\section{2-Fungus culture:}

The fungal isolate $B$. bassiana was isolate from soil samples by Abd El Nasser A. M. Kobisi, Economic Entomology Unit, Plant Protection Department, Desert Research Centre. By using the soil plate method (Warcup, 1950). Both light and electron microscopy were used for examination and identification of the fungal isolate according to (Raper and Fennel, 1965) and (Samson et al., 1995). The B. bassiana isolate was cultured on liquid medium after purification by sub- culting on potato dextrose agar (PDA) medium. One disc contain spores was cut from edge of actively growing culture and inoculated under aseptic condition in each sterilized media (adjusted at $\mathrm{pH} 6.5$ ) 
of Potato dextrose broth (PDB $50 \mathrm{ml}$ ) medium in Erlenmeyer flask (250 $\mathrm{ml}$ capacity). The fungal isolate was transferred to an incubator maintaining $28 \pm 2^{\circ} \mathrm{C}$. After 14 days of incubation period the mycelial mat of isolate was harvested, washed with distilled water for several time, the extract by refluxing in boiled methanol for 2 hours and then filtered off. The mycelial residue was reextracted again for three times. The combined filtrates were concentrated under reduced pressure at temperature not exceeding $35^{\circ} \mathrm{C}$. The obtained residue was kept in refrigerator for investigation against the target insect. The filter of isolate was extracted by nbutanol. This step was repeated until complete extraction. The butanolic extract was filtered on anhydrous of sodium sulphate. Fungal suspension concentrations were adjusted by estimation on a haemocytometer (hirscmann $0.1 \times 0.0025 \mathrm{~mm} 2$ ).

3-Toxicity Test:

A-Method of application on Aphid:

To determinate the effect of the entomopathogenic fungus on $A$. craccivora, assay was carried out on adult (2-3 days old). Three concentrations $\left(1 \times 10^{3}, 1 \times 10^{5}\right.$ and $1 \times 10^{7}$ spores $\left./ \mathrm{ml}\right)$ of fungal suspension were used. Treatments and control represented with 3 replicates and each replicate consisted of ten adults of $A$. craccivora. Each replicate was sprayed with $1 \mathrm{ml}$ of fungal suspension in small plastic cages then transferred to $9 \mathrm{~cm}$ Petri dish. Control was treated with water. Daily mortality rates were noted and dead adults were monitored for mycosis symptoms. Data were analyzed for determination of the lethal concentration $\left(\mathrm{LC}_{50}\right)$.

\section{B-Method of application on C. carnea larvae:}

\section{B.1- Direct effect:}

The residual film technique was used. $3 \mathrm{ml}$ of the desired concentration were evenly spread on a Petri dish surface $(9 \mathrm{~cm}$ in diameter). The solvent allowed being evaporated leaving a film of several concentration of fungal isolate $\left(1 \times 10^{3}, 1 \times 10^{5}\right.$ and $1 \times 10^{7}$ spores $\left./ \mathrm{ml}\right)$ the $2^{\text {nd }}$ larval instar of aphid lion were exposed to the thin film for 24 hour and offer them the appropriate amount of Aphid as food. The concentration was replicated 6 times; 5 petri dishes for each containing three larvae. The control specimens were treated with water.

\section{B.2- Indirect effect:}

The second larval instar of aphid lion, were fed on larvae of Aphid previously sprayed with the previous concentrations of fungal isolate, then immediately placed with $2^{\text {nd }}$ instar larvae of aphid lion The control specimens were treated with water. Daily inspections were conducted.

\section{C- Statistical Analysis and Assessment of Results:}

Data obtained in different tests were subjected to statistical analysis to evaluate the relative efficiency of the isolate. Mortalities were corrected for the natural mortality according to (Abbot's formula, 1925).

The corrected percent $=($ Observed \%-Control \%) x 100/ (100-Control \%) Concentration / mortality regression lines were drawn on probit logarithmic graph according to the method developed by (Finney, 1971).

The $\mathrm{LC}_{50}$ and $\mathrm{LC}_{90}$ values were calculated according to probane 
program.

percent of hatchability of the resulted females were calculated according to (Zidan et al., 1998) as follows:

$\%$ Hatchability $=$ [No. of hatched eggs $/$ No. of deposited eggs $] \times 100$

\section{RESULTS AND DISCUSSION}

\section{1- Toxic effect of $B$. bassiana isolate:}

\section{A-Effect on A. craccivora:}

The lethal effect of $B$. bassiana isolate on $A$. craccivora adults was recorded. As shown in Table (1), the least percentage of adult mortality was $11 \%$, which was recorded with the lowest tested concentration $\left(1 \times 10^{3}\right.$ spores $\left./ \mathrm{ml}\right)$, while The highest percentage of adult mortality was $(54 \%)$ was achieved at $\left(1 \times 10^{7}\right.$ spores $\left./ \mathrm{ml}\right)$, compared with $4 \%$ in natural mortality.

Table (1): Toxic effect of $B$. bassiana isolate on 2-3 days old adult of Aphis craccivora.

\begin{tabular}{|l|c|c|}
\hline \multirow{2}{*}{$\begin{array}{c}\text { Cocn. } \\
\text { spores/ ml }\end{array}$} & \multicolumn{2}{|c|}{ Mortality \% after 3days } \\
\cline { 2 - 3 } & Obs. & Corr. \\
\hline 0 & 4 & 0 \\
\hline $1 \times 10^{3}$ & 11 & 7.29 \\
\hline $1 \times 10^{5}$ & 26 & 22.91 \\
\hline $1 \times 10^{\prime}$ & 54 & 52.08 \\
\hline
\end{tabular}

The effect of $B$. bassiana isolate on A. craccivora adults could be detected on the basis of the calculated $\mathrm{LC}_{50}$ and $\mathrm{LC}_{90}$ values, which recorded $73868 \times 10^{6}$ and $83384 \times 10^{10}$ spores/ml, respectively (Fig 1).

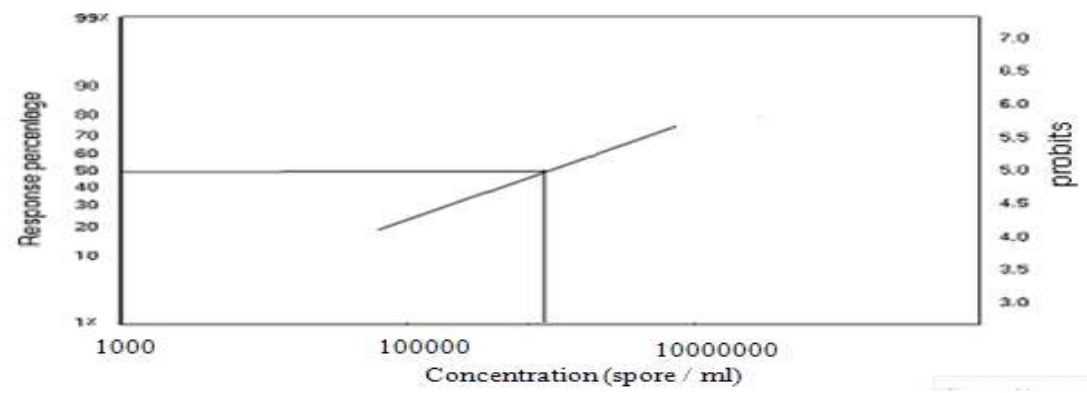

Fig(1): Concentration I mortality regression lines for Aphis craccivora adults treated with $B$. bassiana isolate

According to the recorded data all applied concentrations $B$. bassiana isolate reduced the population of $A$. craccivora adults. (Griffin, 1994 ) stated that the following fact; fungi secret wide array of compound that are biologically active against other organisms. (Goettel and Jaronski, 1997 ) decided $B$. bassiana was ubiquitous as an entomopathogen of a wide range of insects from most insect orders. It is recorded and used in suppressing population of several economically important insects including aphids, whiteflies, mealybugs, lepidopteran eggs and mites 
(Pena et al., 1996; Vandenberg et al., 1998; and Ezz, 2004). These record deth percentages may be attributed to paralysis (mouthpart or midgut) and /or cytotoxin effect (Maketon et al., 2008).

\section{B- Effect on C. carnea larvae:}

Exposure of the $2^{\text {nd }}$ larval instar of aphid lion to $B$. bassiana isolate either through direct or indirect exposure procedure revealed adverse effects on the total percent of larval mortality, which was concentration dependent. Whereas the total larval death recorded $3 \%$ in control trials, data in case of direct exposure revealed 9 to $41 \%$ of larval death at $1 \times 10^{3}$ and $1 \times 10^{7}$ spores/ ml, respectively, Comparable trend was recorded with larvae indirectly exposed. A slight increase in larval mortality was recorded by 5 to $15 \%$, respectively (Table 2), Such mentioned data show that, although the tested $B$. bassiana isolate had the same mode of action in both exposure techniques the drastic larval death in the direct exposure method may be attributed to that the concentration of $B$. bassiana isolate, exceeded that in case of indirect method.

The direct effect of $2^{\text {nd }}$ larval instar of aphid lion to $B$. bassiana isolate, could be detected on the basis of the $\mathrm{LC}_{50}$ and $\mathrm{LC}_{90}$ values which recorded $96279 \times 10^{7}$ and $6935 \times 10^{11}$ spores/ $\mathrm{ml}$, respectively, while the calculated $\mathrm{LC}_{50}$ and $\mathrm{LC}_{90}$ values of indirectly exposure technique recorded $10916 \times 10^{12}$ and $92341 \times 10^{18}$ spores/ ml, respectively, (Fig 2). The result revealed that indirect exposure technique was more effective than direct exposure technique. The data indicated that direct exposure technique was more effective than indirect exposure technique.

A noval bioassay has been developing that allows direct exposing $C$. carnea $2^{\text {nd }}$ larval instar to the tested entomopathogenic fungus $B$. bassiana under laboratory condition. $\mathrm{LC}_{50}$ of $B$. bassiana treated isolate is $>$ the highest concentration tested. That is in agreement to demonstration of (Thungrabeab and Tongma, 2007) who assumed that $B$. bassiana was to be non pathogenic to Chrysopela externa (Hagen) with highest fungal concentration. In disagreement with that, (Sewify and Arnaouty, 1998) found harmful effects of two isolates of Verticillium lecanii on $\mathrm{Ch}$. carnea larvae with significant difference between pathogenicity of the isolates. Nevertheless; different genera, species or strains of entomopathogenic fungi had different pathogenicity and virulence (Goettel, 1995 and Thungrabeab \&Tongma, 2007).

Table (2): Toxic effect of $B$. bassiana isolate on $2^{\text {nd }}$ instar larvae of C. carnea

\begin{tabular}{|l|c|c|c|c|}
\hline \multirow{2}{*}{$\begin{array}{c}\text { Cocn. } \\
\text { spores/ } \mathbf{~ m l}\end{array}$} & \multicolumn{4}{|c|}{ Mortality \% after 3days } \\
\cline { 2 - 5 } & Direct effect & \multicolumn{2}{c|}{ Indirect effect } \\
\cline { 2 - 5 } & Obs. & Corr. & Obs. & Corr. \\
\hline 0 & 3 & 0 & 3 & 0 \\
\hline $1 \times 10^{3}$ & 9 & 6.187 & 5 & 2.06 \\
\hline $1 \times 10^{5}$ & 19 & 16.49 & 9 & 6.18 \\
\hline $1 \times 10^{\prime}$ & 41 & 39.17 & 15 & 12.37 \\
\hline
\end{tabular}


Imam, M. I. and Iman I. Imam.
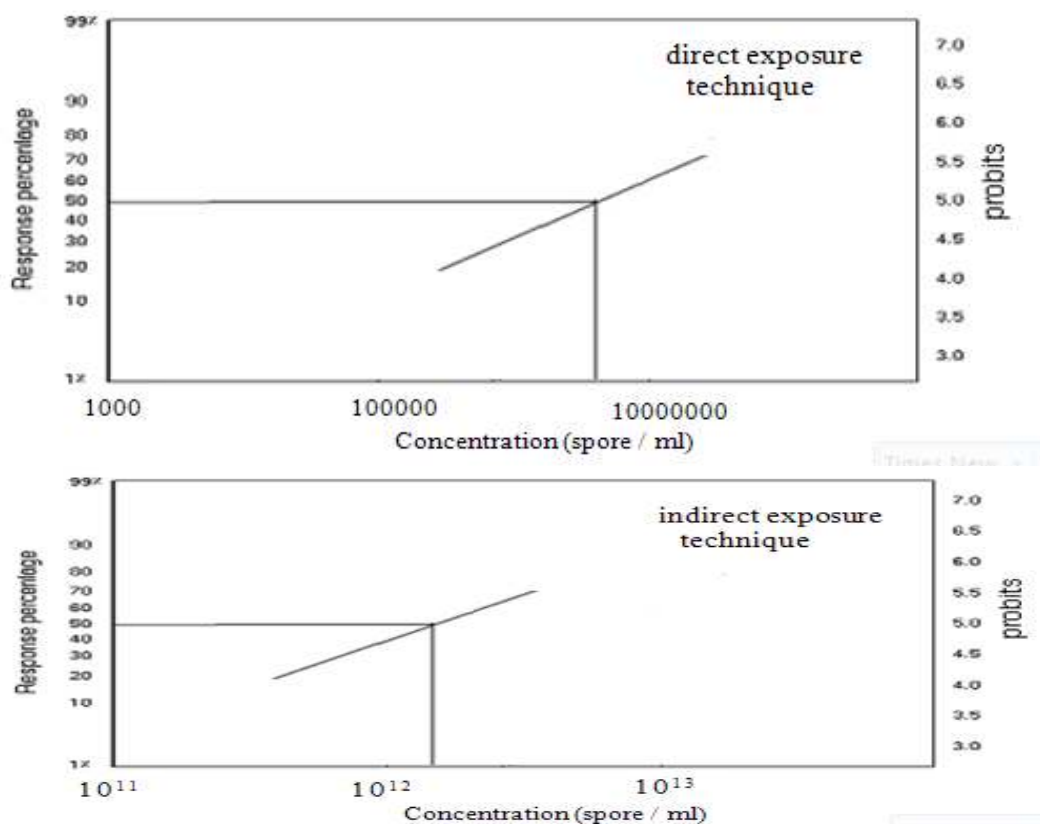

Fig(2): Concentration / mortality regression lines for aphid lion larvae treated with $B$. bassiana isolate

Chrysopela carnea egg hatchability was affected with treatment of to B. bassiana isolate (Table 3), (Fig. 3). In case of direct exposure technique the hatchability percentage decreased by increasing fungal concentration from about 70.86 to $36.14 \%$ at $1 \times 10^{3}$ to $1 \times 10^{3}$ spores/ ml, respectively, compared with about $91.67 \%$ in control females. The fluctuation in the indirect exposure technique did not statistically differ from that recorded in case of control trials.

Table (3): Hatchability percent of $C$. carnea eggs treated by B. bassiana isolate

\begin{tabular}{|l|c|c|c|c|}
\hline \multirow{2}{*}{$\begin{array}{c}\text { Conc. } \\
\text { spores/ }\end{array}$} & \multicolumn{2}{|c|}{ Egg number } & \multicolumn{2}{c|}{ Hatchability \% } \\
\cline { 2 - 5 } & direct effect & indirect effect & direct effect & indirect effect \\
\hline 0 & \multicolumn{2}{|c|}{288} & 70.86 & 91.67 \\
\hline $1 \times 10^{3}$ & 278 & 280 & 61.06 & 91.23 \\
\hline $1 \times 10^{5}$ & 226 & 278 & 36.14 & 90.01 \\
\hline $1 \times 10^{\prime}$ & 166 & 275 & & \\
\hline
\end{tabular}




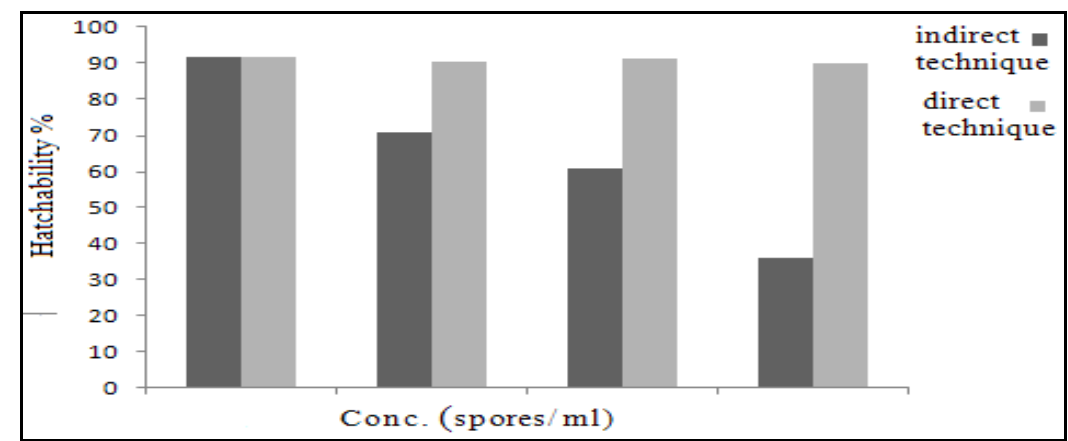

Fig. (3): Percentage of egg hatchability of Ch. carnea eggs treated by B. bassiana isolate

Direct effect caused decreasing in hatchability of Aphid lion eggs with increasing fungal concentration, discrepantly, Pessoa et al., (2005) found innocuous effect of $B$. bassiana on $C$. externa eggs viability.

Sanehdeep et al., (2011) tested the virulence of B. bassiana was against second, third and 4th instar larvae of Spodoptera litura (Fab.) using and noticed that, The eggs descended from treated larvae showed significant decrease in hatchability. Treatment of spiralling whitefly by entomopathogenic fungi, $B$. bassiana caused minimum egg hatchability as compared to control Boopathi Thangavel et al.,(2013)

\section{REFERENCES}

Abbott, W. S. (1925): A method of computing the effectiveness of an insecticide. Jour. Econ. Entomol., 18: 265.

Boopathi Th.; Karuppuchamy M. P.; Mohankumar S. and Ravi M. (2013):

El- Arnaouty, S. A. and A. Ferran(1993): Behavioral relations between the green lacewings, Chrysoperla carnea Steph. And its preys Egypt J. Biol.Pest control 3(1):111-120.

Ezz, N. A. (2004): Isolation and virulence of entomopathogenic fungi associated of microbial pesticides on non-target beneficial arthropods. (Agric. Ecosyst. Environ. 16: 203-254).

Finney, C. E. (1971): Probit Analysis, A statistical treatment of the sigmoid response curve $7^{\text {th }}$ Ed. Cambridge Univ. Press, Cambridge, England FEMS Microbial. Lett. 231: 45-52.

Goettel, M. S. (1995): The utility bioassays in the risk assessment of entomopathogenic fungi. (biotechnology risk assessment USEPA / USDA, enviromental Canada, agriculture and agrioFood, Canda proceeding of the biotechnology, risk assessment symposium, June, $6-8)$. 
Goettel, M. S. and S. T. Jaronski (1997): Safety and registration of microbial agents for control of grasshoppers and locusts. (Memoirs of the entomological society of Canada, 171: 83-99).

Griffin, D. H. (1994): Fungal physiology. Wiley-liss, New York, 458pp.

Hassan, K. A. (2003): Trials for mass- rearing and release for some predacious insect for controlling of pink and spiny bollworms. (Unpublished Ph.D. Thesis, Zagazig Univ., pp180).

Hassan, K. A. and Nahla A. Ezz (2009): Inpact of the entomopathogenic fungus Beauveria bassiana(Bals.) vuill on the predator Chrysopela carnea (Stephens) (Neuroptera: Chrysopidae).,Bull. Ent. Soc. Egypt, Econ.Ser., 35: 9-17.

Maketon, M.; Orosz-Coghlan, P. and Hotaga, D. (2008): Field evaluation metschnikoff (Metarhizium anisopliae) Sorokin in controlling cotton jassid (Amrasca biguttula biguttula) in Aubergine (Solanum aculeatissimum) Int. Agr. Biol., 10(1): 4751.

Mirnoayedi, A. (2001): The effect of experimental release of eggs and larvae of Ch. Carnea insect, Neuroptera, Chrysopidae on the reduction of the attack of Earias insulana,on cotton bolls, in Kermanshah, Iran. (Abst.) (The first conference on integrated oest management 22-23 April, 2001, Cairo).

Pena, J. E.; L. S. Osborne and R. E. Duncan (1996): Potential of fungi as biocontrol agents of polyphagotarsonemus latus (Acari: Tarsonemidae).(Entomophaga, 41: 27-36).

Pessoa, LG. A.; R. S. Cavalc; A Antimoino and B. Souza (2005): Compatibility between Beauveria bassiana and the predator Chrysopela externa in laboratory. ( Pesq. Agropec. Bras., Brasilia, 40(6): 617-619).

Raper, K. B. and and Fennel, D. I. (1965): The genus Aspergillus. Williams and Wilkins Company, Baltimore,MD.

Samson, R.; Hoekstra E., Frisvad, J. and Filtunborg, O. (1995): Introduction of food borne fungi. Baarn and lyngby.

Sanehdeep, K.; Harminder, P.; Preet, K.; Kirandeep, K. and Amarjeet, k.(2011): Effect of different concentrations of Beauveria bassiana on development and reproductive potential of Spodoptera litura (Fabricius), Journal of Biopesticides, 4 (2): 161-168

Sewify, G. H. and El- Arnaouty, S. A (1998): The effect of entomopathogenic fungus Verticillium lecanii (Zimm.) Vegas on nature larvae of Chrysopela carnea (Stephens) (Neuroptera: Chrysopidae) in the laboratory (Acta Zool. Fermica, 209: 233- 237)

Thungrabeab, M. and S. Tongma ( 2007): Effect of entomopathogenic fungi, Beauveria bassiana (Balsam) and Metarhizium anisopliae (Metsch.) on non target insect. (Kmitl Sci. Tech. J. 7(S1): 8-12).

Vandenberg, J. D.; A. M. Shelton; W. T. Wilsey and M. Rams (1998): Assessment of Beauveria bassiana sprays for control of diamondback moth ( Lepidoptera: Plutellidae))on crucifers. (Biological and Microbial control; 624-630). 
Warcup, J. H. (1950): The soil plate method for isolation of fungi from soil. Nature, 166:117-118.

Zidan, Z. H.; Abdel-Megeed, M. I.; Abdel-Hafez, A.; Hussein, N. M.; ElGemeiy, H. M. and Shalaby, M. M. (1998): Toxicological and histological studies of Bacillus thuringiensis, MVPII against larvae of pink and spiny bollworms., Ann. Agri. Sci., 1: 319-332.

دور العازلات الفطرية (BAIS.) كمستحضر مكافحة Chrysopela بيولوجية على من الفول وكذلك اثره على المفترس أسد المن carnea محمد إبراهيم إمام ' و إيمان إبراهيم إمام عمين

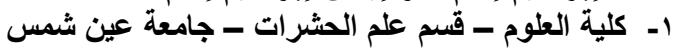

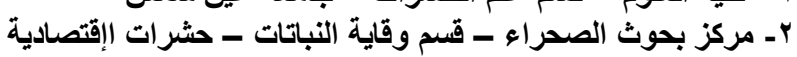

أوضحت النتائج المتحصل عليها من التجريب المعلى ان تاثير عازلات الفطر Beauveria bassiana

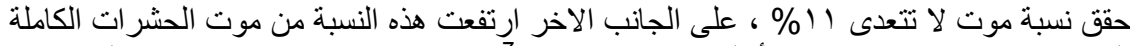

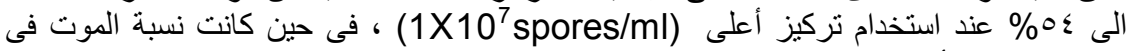

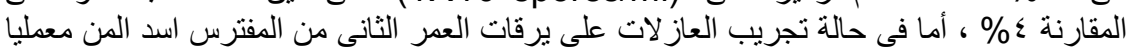

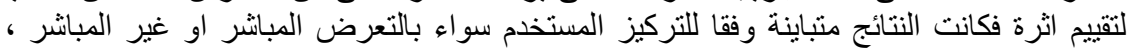

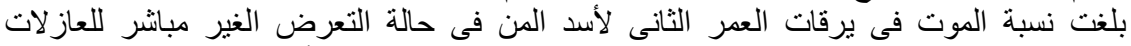

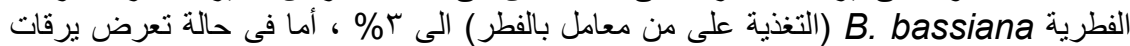

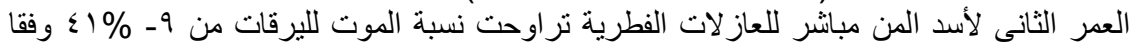

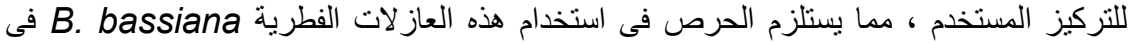

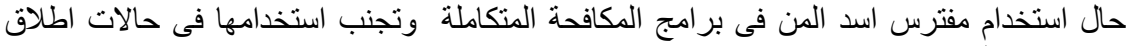

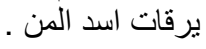

